Otentik's: Jurnal Hukum Kenotariatan (Vol 3, No. 1, Januari 2021)

p-ISSN 2655-5131 e-ISSN 2685-3612

\title{
PERLINDUNGAN HUKUM PEMEGANG HAK ATAS TANAH TERHADAP PENYIMPANGAN PELAKSANAAN PENGADAAN TANAH UNTUK KEPENTINGAN UMUM DENGAN INSTRUMEN PINJAM PAKAI TANAH
}

\author{
Nabila Kamal \\ Magister Kenotariatan, Fakultas Hukum, Universitas Pancasila \\ Email: nabilakamal74@gmail.com
}

\begin{abstract}
ABSTRAK
Pengadaan tanah untuk pembangunan bagi kepentingan umum, tidak terlepas dari masalah seputar pelepasan hak atas tanah, pemberian ganti rugi, dan perlindungan hukum bagi pemegang hak atas tanahnya tersebut. Dalam melakukan pengalihan dan pelepasan hak atas tanah tersebut seringkali terjadi hal-hal yang tidak dapat disepakati antara pemilik tanah dengan pihak yang membutuhkan tanah, terutama mengenai ganti rugi dan perlindungan hukum pemilik tanah. Dalam pelaksanaan pengadaan tanah untuk kepentingan umum seharusnya dilakukan dengan memperhatikan lokasi objek tanah yang akan di bebaskan, sehingga memenuhi rasa keadilan dan pemilik objek tanah tidak mengalami kerugian, pelaksana juga harus memperhatikan hak-hak dari pemilik tanah. Tujuan dilakukannya penelitian ini adalah untuk mengetahui pelaksanaan pengadaan tanah untuk pembangunan bagi kepentingan umum pembangunan jalur pedestrian atau trotoar di kawasan Jalan Kemang Raya Jakarta Selatan sudah sesuai dengan peraturan perundang-undangan yang berlaku yakni Undang-undang Nomor 2 Tahun 2012 tentang Pengadaan Tanah Untuk Pembangunan Bagi Kepentingan Umum beserta peraturan pelaksananya atau tidak. Selain itu, apakah pelaksanaan pengadaan tanah untuk pembagunan jalur pedestrian tersebut dilaksanakan dengan adilan bagi masyarakat yang terdampak tersebut, dan bagaimana perlindungan hukum atas pelepasan hak atas tanah terhadap pemegang hak atas tanah yang terdampak tersebut. Metode pendekatan yang digunakan dalam penelitian tesis ini, yaitu metode penelitian normative dan spesifikasi penelitian yang digunakan adalah secara deskriptif, pengumpulan data penelitian menggunakan menggunakan metode pengumpulan data primer, dan data sekunder, teknik penyajian data yang digunakan adalah deskriptif, dan teknik analitis data yang digunakan adalah analitis kualitatif. Dari penelitian yang telah di lakukan penulis, hasil yang di dapat adalah bahwa pelaksanaan pengadaan tanah untuk pembangunan bagi kepentingan umum dalam hal pembagunan jalur pedestrian atau trotoar di kawasan Jalan Kemang Raya tidak sesuai dengan pelaksanna pengadaan tanah untuk pembangunan bagi kepentingan umum seperti yang diatur dalam Undang-undang No 2 Tahun 2012, dikarenakan terdapat penyimpangan dalam pelaksannannya, yakni dalam hal pengalihan hak atas tanah dari pemilik tanah dengan tidak ada nya kompensasi ganti kerugian terhadap tanah yag akan di gunakan untuk kepentingan umum tersebut, serta tidak adanya keadilan dan perlindungan hukum bagi pemegang hak atas tanah atas tanah nya yang digunakan untuk umum dikarenakan tanah tersebuit dialihkan dengan berdasarkan pinjam pakai tanah, yang dimana dalam kondisi tersebut tanah milik warga di pinjamkan kepada pemerintah tanpa jangka waktu dan tidak ada kejelasan kapan akan di kembalikan, disini terlihat jelas bahwa warga tidak mendapatkan perlindungan hukum, sehingga status tanah yang sudah diambil alih tanpa pemberian kompensasi menjadi milik negara. Selain itu, dalam pelaksanaan pengaadan tanah untuk kepentingan umum pihak yang membutuhkan tanah dibantu oleh pihak dari Kantor Pertanahan setempat, akan tetapi pada kenyaataannya, pihak Kantor Pertanahan tidak dilibatkan. Demikian hasil penelitian ini, diharapkan dapat memberi masukan kepada pemerintah daerah dan instansi-instansi yang membutuhkan lahan untuk pembangunan bagi
\end{abstract}


Otentik's: Jurnal Hukum Kenotariatan (Vol 3, No. 1, Januari 2021)

p-ISSN 2655-5131 e-ISSN 2685-3612

kepentingan umum agar dapat lebih memperhatikan keadilan dan kesejahteraan bagi warga masyarakat yang terkena dampak, agar hak-hak warga negara disini lebih diutamakan dan diperhatikan.

Kata Kunci: Pengadaan Tanah Untuk Kepentingan Umum, Perlindungan Hukum Pemegang Hak Atas Tanah

\begin{abstract}
Land acquisition for development in the public interest, is inseparable from the problems surrounding the relinquishment of land rights, the provision of compensation, and legal protection for the holders of the land rights. In carrying out the transfer and relinquishment of land rights, things often happen that cannot be agreed between the land owner and the party who needs the land, especially regarding compensation and legal protection of the land owner. In the implementation of land acquisition for public purposes, it should be done by taking into account the location of the land object to be released, so that it fulfills a sense of justice and the owner of the land object does not suffer losses, the implementer must also pay attention to the rights of the land owner. The purpose of this research is to find out the implementation of land acquisition for development for the public interest in the development of pedestrian paths or sidewalks in the area of Jalan Kemang Raya, South Jakarta in accordance with applicable laws and regulations, namely Law Number 2 of 2012 concerning Land Procurement for Development for Public interest and its implementing regulations or not. In addition, whether the implementation of land acquisition for the development of the pedestrian path is carried out with justice for the affected communities, and how the legal protection of the release of land rights to holders of land rights affected. The method of approach used in this thesis research, namely normative research methods and research specifications used is descriptive, research data collection using primary data collection methods, and secondary data, data presentation techniques used are descriptive, and data analytical techniques used is qualitative analytical. From the research conducted by the author, the results obtained are that the implementation of land acquisition for development in the public interest in terms of building pedestrian paths or sidewalks in the Jalan Kemang Raya area is not in accordance with the implementation of land acquisition for development for public use as regulated in the Law Law No. 2 of 2012, because there are irregularities in the implementation, namely in the case of transfer of land rights from the land owner with no compensation for land compensation that will be used for public purposes, as well as lack of justice and legal protection for holders land rights to land that are used for public because the land is transferred based on the lease-to-use land, where in the condition the residents' land is loaned to the government without a period of time and it is not clear when it will be returned, here it is clear that the residents do not menda maintain legal protection, so that the status of the land that has been taken over without compensation has become the property of the state. In addition, in the implementation of land acquisition for public purposes, those who need land are assisted by parties from the local Land Office, but in reality, the Land Office is not involved. Thus the results of this study, are expected to provide input to local governments and agencies that need land for development in the public interest so that they can pay more attention to justice and welfare for affected citizens, so that the rights of citizens here are prioritized and paid attention to.
\end{abstract}

Keywords: Land Procurement for Public Interest, Legal Protection of Land Rights Holde 


\section{PENDAHULUAN}

Tanah merupakan kebutuhan dasar manusia. Sejak lahir samai meninggal dunia, manusai membutuhkan tanah untuk tempat hidupnya. Secara kosmologis, tanah adalah tempat manusia tinggal, tempat darimana mereka berasal, dan akan kemana mereka pergi. Dalam hal ini, tanah mempunyai dimensi ekonomi, sosial, kultural, dan politik.

Kepemilikan tanah merupakan sebuah hak asasi manusia yang dilindungi oleh hukum internasional maupun hukum nasional. Dalam hukum nasional, perlindungan hukum hak milik ini diatur dalam Undang-undang Dasar 1945 pasal 28 H ayat (4) dan Undang- undang Nomor 39 Tahun 1999 tentang Hak Asasi Manusia. Dengan dikeluarkannya Undang- undang Pokok Agraria Nomor 5 Tahun 1960 yang merupakan Hukum Tanah Nasional Indonesia, memberikan kepastian Hukum mengenai hak atas tanah bagi rakyat Indonesia.

Tujuannya adalah akan mewujudkan apa yang digariskan dalam pasal 33 ayat (3) Undangundang Dasar 1945, bahwa :

"Bumi,air dan kekayaan alam yang terkandung didalamnya yang penguasaannya ditugaskan kepada Negara Republik Indonesia harus dipergunakan sebesar-besarnya untuk kemakmuran rakyat."

Untuk melaksanakan ketentuan pasal 18 UUPA tersebut ditetapkan Undang-Undang Nomor 20 tahun 1961 tentang Pencabutan Hak-Hak atas Tanah dan Benda-Benda yang ada di Atasnya (Lembaran Negara Republik Indonesia Tahun 1961 Nomor 288, Tambahan Lembaran Negara Republik Indonesia Nomor 2324) selanjutnya disebut UU No.21/1961, yang kemudian tidak berlaku lagi dengan disahkannya Undang-undang Nomor 2 Tahun 2012 Tentang Pengadaan Tanah bagi Pembangunan Untuk Kepentingan Umum.

Hukum Tanah Nasional mengakui dan menghormati hak masyarakat atas tanah dan benda yang berkaitan dengan tanah serta memberikan wewenang yang bersifat publik kepada negara berupa kewenangan untuk mengadakan peraturan, membuat kebijakan, mengadakan pengelolaan,serta menyelenggarakan dan mengadakan pengawasan yang tertuang dalam pokokpokok Pengadaan Tanah sebagai berikut :

1. Pemerintah dan pemerintah daerah menjamin tersedianya tanah untuk kepentingan umum dan pendanaannya.

2. Pengadaan Tanah untuk kepentingan umum diselenggarakan sesuai dengan :

a. Rencana Tata Ruang Wilayah

b. Rencana Pembangunan Nasional/Daerah

c. Rencana Strategis, dan

d. Rencana kerja setiap instansi yang memerlukan tanah. 
Otentik's: Jurnal Hukum Kenotariatan (Vol 3, No. 1, Januari 2021)

p-ISSN 2655-5131 e-ISSN 2685-3612

3. Pengadaan Tanah diselenggarakan melalui perencanaan dengan melibatkan semua - pemangku dan pengampu kepentingan.

4. Penyelenggaraan Pengadaan Tanah memperhatikan keseimbangan antara kepentingan pembangunan dan kepentingan masyarakat

Pengambilalihan lahan atau tanah milik masyarakat tersebut seyogyanya dilakukan dengan pengikatan dan pengalihan hak atas tanah melalui suatu perjanjian. Perjanjian adalah suatu peristiwa dimana seseorang berjanji kepada seorang lainnya atau dimana dua orang itu saling berjanji untuk melaksanakan suatu hal. Ketentuan-ketentuan mengenai hal ini diatur dalam pasal 1313 sampai pasal 1351 Kitab Undang-undang Hukum Perdata (KUHPerdata). Menurut pasal 1313, yang dimaskud dengan perjanjian adalah suatu perbuatan, dengan mana satu orang atau lebih mengikatkan dirinya terhadap satu orang lain atau lebih. Apabila telah tercapai suatu kesepakatan mengenai bentuk dan besarnya ganti rugi, maka baru dapat dilakukan pembayaran ganti rugi yang diikuti dengan pelepasan atau penyerahan hak atas tanah yang bersangkutan.

Perjanjian yang kerap kali digunakan untuk pengalihan tanah untuk kepentingan umum adalah Berita Acara Pelepasan Hak atas Tanah, dimana para pemilik tanah menandatangani pelepasan tersebut di hadapan Badan Pertanahan Nasional sebagai bukti pelepasan tanah miliknya. Dalam hal ini, pembebasan lahan yang dilakukan pemerintah daerah dalam pembangunan trotoar disekitar Jalan Kemang Raya, hanyalah menggunakan perjanjian pinjam pakai tanah sebagai alas dasar pengambilalihan tanah milik masyarakat di Jalan Kemang Raya.

Perjanjian pinjam pakai diatur dalam Pasal 1740 sampai dengan pasal 1753 Kitab UndangUndang Hukum Perdata.

Pasal 1740 KUHPerdata menyatakan “ Pinjam pakai adala suatu perjanjian dengan mana pihak yang satu memberikan suatu barang kepada pihak yang lainnya untuk dipakai dengan Cuma-Cuma, dengan syarat bahwa yang menerima barang ini, setelah memakainya atau setelah lewatnya suatu waktu tertentu, akan mengembalikannya.

Perjanjian pinjam pakai merupakan perjanjian sepihak, maksudnya adalah bahwa pihak yang meminjamkan berkewajiban memberikan prestasi kepada peminjam yaitu berupa hak pinjam pakai, sedangkan pihak peminjam tidak berkewajiban memberikan kontraprestasi apapun kepada pihak yang meminjamkan.

Pada dasarnya hukum dibuat untuk memberi kenyamanan, ketentraman, keselamatan dan perlindungan bagi setiap warga negara, termasuk untuk mmberi rambu-rambu atau batasan- batasa baik perbuatan/tindakan sebagai warga negara maupun sebagai penyelenggara pemerintahan. Untuk itu hukum yang dibuat harus berisi nilai-nilai mulia seperti nilai ketuhanan, etika, moral, sopan santun, dan lain sebagainya, agar tujuan di atas itu benar- benar memberi pelayanan terbaiknya bagi 
Otentik's: Jurnal Hukum Kenotariatan (Vol 3, No. 1, Januari 2021)

p-ISSN 2655-5131 e-ISSN 2685-3612

semua lapisan masyarakat. Dalam mencapai tujuan sebagaimana diatas, setiap produk peraturan perundang-undangan yang dibentuk harus memenuhi syarat-syarat tertentu yang menjadi ukuran umum dan khusus dari setiap pembangunan hukum/peraturan perundang-undangan.

\section{PENDEKATAN MASALAH}

Penelitian ini menggunakan metode pendekatan hukum normatif. Penelitian hukum normatif adalah metode penelitian hukum yang dilakukan dengan meneliti bahan pustaka atau data sekunder.

Dalam kaitannya dengan pendekatan normative, penelitian ini menggunakan beberapa pendekatan:

1. Pendekatan perundang-undangan adalah suatu pendekatan yang dilakukan terhadap berbagai aturan hukum yang berkaitan dengan Undang-Undang Nomor 2 Tahun 2012 tengan Pengadaan Tanah Bagi Kepentingan Umum, beserta peraturan-peraturan pendukungnya.

2. Pendekatan asas-asas dari pelaksanaan pengadaan tanah bagi kepentingan umum, yaitu suatu pendekatan yang dilakukan terhadap beberapa asa yang berkaitan dengan pelaksanaan pengadaan tanah bagi kepentingan umum.

\section{METODE}

\section{Sifat Penelitian}

Penelitian ini lebih bersifat deskriptif analisis yaitu suatu penelitian yang berusaha memberikan gambaran secara menyeluruh, mendalam, tentang suatu keadaan atau gejala yang diteliti, dimana dalam hal ini penulis memberi gambaran secara detail dan sistematis mengenai proses pengadaan tanah bagi kepentngan umum serta mengenai proses tata cara dan prosedur pelaksanaan pembebasan lahan untuk keperntingan umum dan perlindungsn hukum yang diterima masyarakat pemilik tanah sesuai atau tidaknya dngan peraturan yang mengatur mengenai pengadaan tanah bagi kepentingan umum, terkait pengadaan tanah dalam hal pembangunan trotoar di sepanjang Jalan Kemang Raya, Jakarta Selatan.

\section{Teknik Pengumpulan Data}

Bahan hukum yang dikaji dan dianalisis dalam penelitian hukum normative meliputi bahan hukum primer, sekunder dan tersier. Teknik untuk mengkaji dan mengumpulkan ketiga bahan hukum tersebut, yaitu dengan menggunakan bahan hukum sekunder, yaitu menggunkan studi documenter, selain itu,penelitian ini juga menggunakan bahan hukum primer yaitu wawancara yang dilakukan degan pihak- pihak yang terkait dalam pelaksanaan pengadaan tanah bagi kepentingan umum dalam hal pembangunan jaur pedestrian di sepanjang jalan kemang raya.

Teknik Pengumpulan data yang digunakan dalam penelitian yang dilakukan adalah dengan studi dokumen atau penelusuran literature dan kepustakaan, dengan mempelajari dan membaca 
Otentik's: Jurnal Hukum Kenotariatan (Vol 3, No. 1, Januari 2021)

$$
\text { p-ISSN 2655-5131 e-ISSN 2685-3612 }
$$

bahan-bahan hukum yang terkait dengan pene5litian ini serta berdasarkan wawancara dengan pihak-pihak yang terkait.

\section{Teknik Penyajian Data}

Pada laporan penelitian, bagian hasil penilian terdapat Bahasa mngenai deskripsi data, analisa data dan pembahasan. Deskriptif data adalah kgiatan menyajikan data dari data yang dikumpulkam. Data yang dikumpulkan dalam proses pengumpulan data merupakan data yang berserakan, tidak beraturan dan sulit di baca, agar tersusun dalam bentuk yang teratur dan mudah dibaca maka dilakukan penyajian data atau penyusunan data. Dengan demikian penyajian data adalah kegiatan menyusun data mentah menjadi sebuah data yang siap untuk dibaca dan menjadi lebih teratur, dalam hal ini penulis menyajikan data secara deskriptif mengenai permasalahan pembebasan lahan terkait pengadaan tanah bagi kepentingan umum untuk pembangunan trotoar di sepanjang Jalan Kemag Raya Jakarta Selatan.

\section{Teknik Analisa data}

Metode analisa data yang digunakan dalam penelitian ini bersifat kualitatif, yaitu dengan mempelajari seluruh data yang diperoleh dari studi kepustakaan, kemudian dilakukan analisis sehingga memperoleh hasil penelitian yang bersifat deskriptif. Metode penelitian ini tepat untuk menganalisa kasus permasalahan pembebasan lahan terkait pengadaan tanah bagi kepentingan umum untuk pembangunan trotoar di sepanjang Jalan Kemang Raya, Jakarta Selatan.

\section{HASIL DAN PEMBAHASAN}

Pembangunan trotoar atau jalur pedestrian di kawasan jalan Kemang raya sepanjang $-/+7,5$ km (tujuh koma lima kilometre) dengan lebar -/+ 4 m (empat meter) adalah merupakan pengadaan tanah bagi kepentingan umum, yang dimana dalam pelaksanaan nya harus berdasarkan undangundang yang mengatur nya yakni undang-undang No. 2 Tahun 2012 tentang Pengadaan Tanah Bagi Kepentingan umum beserta dengan peraturan pendukung lainnya, seperti Peraturan Presiden Nomor 71 tahun 2012 dan No. 148 tahun 2015.

Disini akan dibahas bagaimana prosedur pelaksanaan pengadaan tanah bagi kepentingan umum tersebut, selain bagaimana prosedur pelaksanaannya juga akan membahas mengenai perlindungan hukum bagi pemegang hak atas tanah nya serta bagaimana pelepasan hak nya yang ditentukan oleh pemerintah daerah, adakah akibat dari pelaksanaan pengadaan tanah bagi kepentingan umum ini yang menimbulkan keresahan masyarakat bahkan sampai kerugian materil maupun imateril bagi masyarakat sekitar jalan Kemang raya. 
Otentik's: Jurnal Hukum Kenotariatan (Vol 3, No. 1, Januari 2021)

p-ISSN 2655-5131 e-ISSN 2685-3612

\section{Tahapan Pelaksanaan Pengadaan Tanah Bagi Kepentingan Umum}

Apabila di teliti lebih dalam, ada beberapa tahapan dalam pengadaan tanah bagi kepentingan umum yang harus dilalui dan dipatuhi oleh pihak yang mebutuhkan tanah, tahapan-tahapan tersebut adalah sebagai berikut :

1. Tahapan Perencanaan Pengadaan Tanah

Perencanaan pengadaan tanah dilaksanakan oleh instansi yang memerlukan tanah bersamasama instansi teknis terkait dan dapat mengikutsertakan lembaga professional. Dalam Pelaksanaan pembangunan jalur pedestrian atau trotoar di kawasan Kemang Raya, dalam tahap perencanaan diatas point $\mathrm{h}$ dan point i tidak dilaksanakan, pihak yang membutuhkan yanah yakni Dinas Bina Marga tidak mensosialisasaikan mengenai perkiraan nilai tanah dan nilai ganti kerugian objek pengadaan tanah dan/atau kerugian lain yang dapat dinilai. Selain itu, seperti dijelaskan dalam point rencana penganggaran harus menguraikan besaran dana dan sumber san rencana alokasi dana untuk perencanaan, persiapan, pelaksanaan, penyerahan hasil, administrasi dan pengelolaan serta sosialisasi, tetapi dalam pembangunan jalur pedestrian di Kemang Jakarta Selatan, Dinas Bina Marga walaupun dari pihak Walikota Jakarta Selatan, tidak melakukan hal tersebut.

\section{Tahapan Persiapan}

Atas dasar dokumen perencanaan yang telah dibuat, instansi yang memerlukan tanah tersebut bersama pemerintah provinsi melaksanakan kegiatan :

a. Pemberitahuan rencana pembangunan;

b. Pendataan awal lokasi;

c. Konsultasi public rencana pembangunan.

Untuk melaksanakan kegiatan-kegiatan tersebut, Gubernur membentuk tim persiapan dalam waktu paling lama 2 (dua) hari kerja sejak dokumen perencanaan pengadaan tanah diterima secara resmi oleh gubernur, yang beranggotakan bupati/walikota, satuan kerja perangkat daerah provinsi terkait lainnya.

Pengumuman penetapan lokasi pembangunan dilaksanakan paling lambat 2 (dua) hari kerja sejak dikeluarkan penetapan lokasi pembangunan dan dilakukan selama paling kurang 7 (tujuh) hari kerja. Pengumuman melalui media cetak dilaksanakan melalui surat kabar harian local dan nasional paling sedikit 1 (satu) kali penerbitan pada hari kerja, sedangkan pengumuman melalui media elektronik dilaksanakan melalui laman website pemerintah provinsi, pemerintah kabupaten/kota atau instansi yang memerlukan tanah.

3. Tahapan Pelaksanaan

Berdasarkan penetapan lokasi pembangunan untuk kpentingan umum, instansi yang memerlukan tanah mengajukan pelaksanaan pengadaan tanah kepada lembaga pertanahan. 
Otentik's: Jurnal Hukum Kenotariatan (Vol 3, No. 1, Januari 2021)

p-ISSN 2655-5131 e-ISSN 2685-3612

Pelaksanaan pengadaan tanah di selenggarakan oleh menteri berdasarkan Perpres 148/2015, dan dilaksanakan oleh Kepala Kantor Wilayah BPN, selaku Ketua Pelaksana Pengadaan Tanah.

Susunan keanggotaan pelaksanaan pengadaan tanah ditetapkan oleh Ketua Pelaksana Pengadaan Tanah yang berunsurkan paling kurang :

a. Pejabat yang membidangi urusan Pengadaan Tanah di lingkungan Kantor Wilayah BPN;

b. Kepala Kantor Pertanahan setempat pada loaksi Pengadaan Tanah;

c. Pejabat satuan kerja perangkat daerah provinsi yang membintangi urusan pertanahan;

d. Camat setempat pada lokasi Pengadaan Tanah; dan

e. Lurah/kepala desa atau nama lain pada lokasi Pengadaan Tanah.

Penetapan pelaksana pegadaan tanah dilakukan dalam jangka waktu paling lama 2 (dua) hari kerja sejak diterimanya pengajuan pelaksanaan pengadaan tanah (Pasal 49 Perpres Nomor 71/2012 juncto Perpres Nomor 148/2015). Kepala Kantor Ketua Pelaksanaan Pengadaan Tanah, dengan mempertimbangkan efisiensi,efektifitas, kondisi geografis, dan sumber daya manusia, dalam waktu paling lama 2(dua) hari kerja sejak diterimanya pengajuan pelaksanaan pengadaan tanah. Dalam hal Kepala Kantor Pertanahan sebagai Ketua Pelaksana Pengadaan Tanah, membentuk Pelaksana Pengadaan Tanah dalam waktu paling lama 2(dua) hari kerja sejak diterimanya penugasan,dengan susunan keanggotaan paling kurang berunsurkan:

a. Pejabat yang membidangi urusan Pengadaan Tanah di lingkungan Kantor Pertanahan;

b. Pejabat pada Kantor Pertanahan setempat pada lokasi Pengadaan Tanah;

c. Pejabat satuan kerja perangkat daerah provinsi yang membidangi urusan pertanahan;

d. Camat setempat pada lokasi Pengadaan Tanah;

e. Lurah/kepala desa atau nama lain pada lokasi Pengadaan Tanah.

\section{Penilaian Ganti Kerugian}

Penetapan besarnya ganti kerugian dilakukan oleh Ketua Pelaksana Pengadaan Tanah berdasarkan hasil penilaian jasa penilai atau penilai public yang ditetapkan oleh Ketua Pelaksana Pengadaan Tanah berdasarkan hasil pengadaan jasa penilai yang dilakukan oleh instansi yang memerlukan tanah dalam waktu paling lama 30 (tiga puluh) thari kerja, dan dilakukan sesuai dengan ketentuan peraturan perundang-undangan dibidang pengadaan barang dan jasa Pemerintah. Jika pemilihan penilai tidak dapat dilaksanakan, Ketua Pengadaan Tanah menunjuk penilai public. Menurut ketentuan Pasal 1 angka 11 Perpres Nomor 71 Tahun 2012 Perpres Nomor 148 Tahun 2015 yang dimaksud penilai pertanahan, yang selanjutnya disebut penilai adalah orang perseorangan yang melaukan penilaian secara independen dan professional yang telah mendapat izin praktik penilaian dari Menteri Keuangan dan telah mendapat lisensi dari Kementerian utuk menghitung nilai/harga objek pengadaan tanah. Sedangkan penilai public menurut ketentuan Paasal 
Otentik's: Jurnal Hukum Kenotariatan (Vol 3, No. 1, Januari 2021)

$$
\text { p-ISSN 2655-5131 e-ISSN 2685-3612 }
$$

1 angka 12 Perpres Nomor 71 Tahun 2012 adalah penilai yang telah memperoleh izin dari Menteri Keuangan untuk memberikan jasa penilaian. Pelaksanaan tugas penilai dilaksanakan paling lama 30 (tiga puluh) hari kerja sejak ditetapkannya Penilai oleh Ketua Pelaksana Pengadaan Tanah, dengan tugas melakukan penilaian besarnya ganti kerugian bidang per bidang tanah meliputi:

- Tanah;

- Ruang atas tanah dan bawah tanah;

- Bangunan;

- Tanaman;

- Benda yang berkaitan dengan tanah; dan/atau

- Kerugian lain yang dapat dinilai.

Nilai ganti kerugian yang dinilai oleh penilai merupakan nilai pada saat pengumuman penetapan lokasi pembangunan untuk kepentingan umum, dan merupakan nilai tunggal untuk bidang perbidang tanah. Dalam bekerja penilai pertanahan menggunakan Standar Penilaian Indonesia 306 (SPI 306) tahun 2013 sebagai acuan.

\section{Musyawarah penetapan Ganti Kerugian}

Pelaksanaan pengadaan tanah melaksanakan musyawarah dengan pihak yang berhak dengan mengikutsertakan instansi yang memerlukan tanah dalam waktu 30 (tiga puluh) hari kerja sejak hasil penilaian dari penilai diterima oleh Ketua Pelaksana Pengadaan Tanah dan undangan paling lambat disampaikan paling lambat 2 (dua) hari kerja sebelum tanggal pelaksanaan musyawarah penetapan ganti kerugian. Jika belum tercapai kesepakatan musyawarah dapat dilaksanakan lebih dari 1 (satu) kali.

Jika tidak terjadi kesepakatan mengenai betuk dan/atau besarnya ganti kerugian, pihak yang berhak dapat mengajukan keberatan kepada pengadilan negeri setempat dalam jagka waktu paling lama 14 (empat belas) hari kerja setelah ditanda tangani berita acara hasil musyawarah, dan pengadilan negeri memutus bentuk dan/atau besarnya ganti kerugian dalam waktu paling lama 30 (tiga puluh) hari kerja sejak diterimanya pengajuan keberatan. Apabila masih ada pihak yang keberatan terhadap putusan pengadilan negeri tersebut, maka dalam waktu paling lama 14 (empat belas) hari kerja dapat mengajukan kasasi kepada Mahkamah Agung, dan Mahkamah Agung wajib memberiakan putusan dalam waktu 30 (tiga puluh) hari kerja sejak permohonan kasasi diterima. Putusan Pengadilan Negeri/Mahkamah Agung yang telah memperoleh kekuatan hukum tetap menjadi dasar pembayaran ganti kerugian kepada pihak yang mengajukan keberatan.

\section{Pemberian Ganti Kerugian}

Ganti kerugian diberikan kepada pihak yang berhak berdasarkan hasil penilaian yang ditetapkan dalam musyawarah dan/atau putusan pengadilan 
negeri/Mahkamah Agung, dan pada prinsipnya diserahkan langung kepada pihak yang berhak, dalam bentuk:

- Uang;

- Tanah pengganti;

- Permukiman kembali;

- Kepemilikan saham; atau

- Bentuk lain yang disetujui oleh kedua belah pihak

Bentuk ganti kerugian, baik berdiri sendiri maupun gabungan dari beberapa bentuk ganti kerugian diberikan sesuai dengan nilai ganti kerugian yang nominalnya sama dengan nilai yang ditetapkan oleh panitia. Meski bentuk kerugian bermacam- macam, namun menurut Pasal 75 ayat 1 Perpres Nomor 71 Tahun 2012, pelaksana pengadaan tanah mengutamakan pemberian ganti kerugian dalam bentuk uang. Pemberian ganti kerugian dalam bnetu uang dilakukan paling lama dalam 7 (tujuh) hari kerja sejak penetapan bentuk ganti kerugian oleh pelaksana pengadaan tanah, dilakukan oleh instansi yang memerlukan tanah berdasarkan validasi dari Ketua Pelaksanaan Pengadaan Tanah atau pejabat yang ditunjuk dalam waktu paling lama 3 (tiga) hari kerja sejak berita acara kesepakatan bentuk ganti kerugian di tanda tangani, dan ganti kerugian tersebut diberikan dalam bentuk mata uang rupiah sebagaimana dijelaskan dalam Pasal 76 Perpres Nomor 71 Tahun 2012 juncto Perpres Nomor 148 Tahun 2015. Pemberian ganti kerugian dalam bentuk tanah pengganti diberikan oleh instansi yang memerlukan tanah dan atas nama pihak yag berhak setelah mendapat permintaan tertulis dar Ketua Pelaksana Pengadaan Tanah. Pemberian ganti kerugian dengan tanah pengganti ini dilakukan bersamaan dengan pelepasan hak oleh pihak yang berhak tanpa menunggu tersedianya tanah pengganti.

\section{Pelepasan Tanah Instansi}

Pelepasan objek pengadaan tanah untuk kepentingan umum yang dimiliki pemerintah dilakukan sesuai dengan ketentuan peraturan perundang-undangan yang mengatur pengelolaan barang milik negara/daerah, sedangkan pelepasan objek pengadaan tanah untuk kepentingan umum yang dikuasai oleh pemerintah atau dikuasai/di miliki oleh Badan Usaha Milik Negara/Badan Usaha Milik Daerah. Pelepasan objek pengadaan tanah tersebut tidak diberikan ganti kerugian, kecuali :

- Objek pengadaan tanah yang telah berdiri bangunan tanah yang dipergunakan secara aktif untuk penyelenggaraan tugas pemerintahan ;

- Objek pengadaan tanah yang dimiliki/dikuasai oleh Badan Usaha Milik Negara/Badan Usaha Milik Daerah; 


$$
\text { p-ISSN 2655-5131 e-ISSN 2685-3612 }
$$

- Objek pengadaan tanah kas desa.

Dalam tahap pelaksanaan di jelaskan bahwa yang menjadi ketua pelaksana pengadaan tanah seharusnya adalah pihak dari Kantor Badan Pertanahan Nasional wilayah setempat. Akan tetapi dalam pengadaan tanah bagi kepentingan umum terkait pembangunan jalur pedestrian di kawasan Jalan Kemang Raya sejak awal pihak kantor pertanahan setempat tidak pernah dilibatkan, bahkan pada saat di gelar pertemuan di kantor Walikota Jakarta Selatan yang dihadirkan hanya pihak dari Dinas Bina Marga, Dinas Cipta Karya dan Dinas Perhubungan, tidak ada perwakilan dari pihak Kantor Pertanahan setempat, dikarenakan Kantor Pertanahan setempat juga tidak mendapatkan undangan yang di buat oleh walikota Jakarta selatan. Selain itu, untuk menetukan luas pihak yang seharusnya melakukan pengukuran dan pemetaan lokasi adalah pihak dari Kantor Pertanahan setempat. Disini penyimpangna terjadi dari pengadaan tanah yang dilakukan oleh pemerintah daerah bahwa pelaksanaan pembangunan jalur pedestrian termasuk pengaadaan tanah untuk pembangunan bagi kepentingan umum, tetapi pelaksanaanya tidak sesuai denga proses pengadaan tanah untuk pembangunan bagi kepentingan umum sebagaimana yang diatur dalam Undang-undang Nomor 2 Tahun 2012 tentang Pengadaan tanah untuk pembangunan bagi kepentingan umum.

Dalam tahap pelaksanaan ini juga dijelaskan mengenai ganti kerugian yang seharusnya diterima oleh para pihak yang tanah nya digunakan untuk pembangunan jalur pedestrian tersebut. Dalam pasal 36 Undang-undang Nomor 2 Tahun 2012 tentang Pengadaan Tanah Untuk Pembangunan Bagi Kepentingan Umum dijelaskan bahwa pemberian ganti kerugian dapat diberikan dalam bentuk :

a. Uang;

b. Tanah pengganti;

c. Permukiman kembali;

d. Kepemilikan saham;

e. Bentuk lain yang disetujui oleh kedua belah pihak

Dalam pasal 75 Peraturan Pemerintah Nomor 71 Tahun 2012 tentang Penyelenggaraan Pengadaan Tanah bagi Pembangunan untuk Kepentingan Umum menjelaskan bahwa dalam musyawarah sebagaimana dimaksud dalam Pasal 68 pelaksana pengadaan tanah mengutamakan gantu rugi dalam bentuk uang.

Tetapi pada kenyataannya dalam pengadaan tanah untuk kepentingan umum dalam hal pembangunan jalur pedestrian di jalan Kemang Raya, Pemerintah Daerah tidak memberikan bentuk ganti rugi dalam bentuk apapun, dalam beberapa kali pertemuan Walikota Jakarta Selatan Bapak Marullah Matali menyebutkan bahwa akan mengubah peruntukan di daerah Kemang yang semula hanya untuk perumahan, akan di ubah menjadi komersil, akan tetapi hal tersebut tidak dituangkan 
Otentik's: Jurnal Hukum Kenotariatan (Vol 3, No. 1, Januari 2021)

p-ISSN 2655-5131 e-ISSN 2685-3612

ke dalam perjanjian kerjasama tersebut..

Sampai sekarang pembangunan jalur pedestrian di sepanjang Jalan Kemang Raya masih tertunda, karena banyak warga setempat yang belum menyetujui pengambilan hak tersbut. Disamping itu, sudah ada tanah yang dibangun jakur pedestrian, yakni bidang-bidang tanah yang memang statusnya adalah milik negara, sehingga dapat digunakan untuk kepentingan umum, bidang-bidang tanah dengan status sudah dilakukan pembongkaran dan dibangun jalur pedestran. Untuk itu kondisi jalan kemang raya kini masih terbilang tidak rapi, karena masih banyak ihakpihak yng tidak mau menyerahkan sebidang tanah nya dengan Cuma-Cuma, ada beberapa masyarakat yang kehilangan garasi rumah nya sehingga tidak dapat untuk memarkir mobil nya di dalam rumahnya, seharusnya phak pemerintah daerah juga memikirkan akibat-akibat yang akan di alami oleh masyarakat sekitar jalan kemang raya.

Berdasarkan wawancara saya dengan Bapak Yusuf sebagai coordinator di PTSP (Pelayanan Terpada Satu Pintu) bahwa tanah - tanah yang sudah dibebaskan dan dibangun menjadi trotoar adalah tanah-tanah yang memang berstatus peruntukannya adalah unutk umum yang dikelan dengan zona TPZ dimana tanah dengan status tersebut harus diserahkan kepada Pemerintah Daerah, untuk itu pihak penyelenggara dapat langsung melakukan eksekusi terhadap tanah tersebut. Oleh karena itu, tanah-tanah yang memang peruntukannya untuk rumah tinggal dan tidak terpotong dengan peruntukan untuk umum belum dibongkar, lantaran pihak penyelenggara belum sepenuhnya mendapat persetujuan dari pemilik tanah tersebut.

4. Tahapan Penyerahan Hasil

Penyerahan hasil pengadaan tanah kepada instansi yang memerlukan tanah dilakukan setelah :

a. Pemberian ganti kerugian kepada pihak yang berhak dan pelepasan hak telah dilakukan; dan/atau

b. Pemberian ganti kerugian telah dititipkan ke Pengadilan.

Ketua Pelaksana Pengadaan Tanah menyerahkan kepada instansi yang memerlukan tanah berupa bidang tanah disertai data pengadaan tanah dan dokumen pengadaan tanah, paling lama 3 (tiga) hari kerja sejak pelepasan hak objek pengadaan tanah. Penyerahan hasil pengadaan tanah dilakukan dengan berita acara untuk selanjutnya dipergunakan oleh instansi yang memerlukan tanahguna pendaftaran/pensertipikatan yang wajib dilakukan dalam waktu paling lama 30 (tiga puluh) hari kerja sejak penyerahan hasil pengadaan tanah.

Dalam pengadaan tanah pembangunan jalaur pedestrian di jalan Kemang Raya, penyerahan hasil tidak dilakukan setelah atau pada saat penberian ganti kerugian kepada pihak yang berhak, akan tetapi penyerahan lahan atau tanah diserahkan pada saat atau setelah penandatangan perjanjian 
Otentik's: Jurnal Hukum Kenotariatan (Vol 3, No. 1, Januari 2021)

p-ISSN 2655-5131 e-ISSN 2685-3612

kerjasama yang dalam hal ini perjanjian pinjam pakai tanah, tanpa ada kompensasi yang di berikan pihak yang membutuhkan tanah ataupun dari pemerintah daerah, seharusnya penyerahan hasil yang di buat dalam Berita Acara Serah Terima dilakukan pada saat yang sama dengan pemberian kompensasi atau ganti kerugian kepada pihak pemegang ha katas tanah tersebut dan dilakukan oleh lembaga pertanahan setempat.

Tahapan yang dilakukan dalam pembangunan jalur pedestrian di jalan Kemang Raya adalah :

a. Tahapan penentuan trase;

b. Pendataan pemilik lahan;

c. Pendataan status zonasi;

d. pendataan status izin bangunan;

e. pengukuran luas;

f. penyerahan dokumen dari pemilik;

g. penandatangana perjanjian kerjasama.

Perlindungan Hukum bagi masyarakat pemegang ha katas tanah atas tanah miliknya yang digunakan oleh pemerintah daerah untuk kepentingan umum

Seperti kita ketahui dalam Undang-Undang Dasar 1945 Pasal 28 H ayat 2 menyebutkan bahwa

“ setiap orang berhak mendapatkan kemudahan dan perlakuan khusus untuk memperoleh kesempatan dan manfaat yang sama guna mencapai persamaan dan keadilan". Apabila dikaitkan dengan kasus yang terjadi pada pembangunan jalur pedestrian di sepanjang jalan Kemang Raya, disini penulis menyimpulkan bahwa keadilan tidak berwujud disini, dimana pemilik tanah yang tanah nya digunakan untuk pembangunan bagi kepentingan umum tersebut dilakukan secara sewenang- wenang, seperti hal nya pengalihan hak atas tanah dilakukan hanya dengan penandatanagan perjanjian pinjam pakai dibawah tangan, seperti kita ketahui dalam Kitab UndangUndang Hukum Perdata Pasal 1740 dijelaskan bahwa “ perjanjian pinjam pakai adalah suatu perjanjian dengan mana pihak yang satu memberikan suatu barang kepada pihak yag lainnya untuk dipakai dengan cuma cuma, dengan syarat bahwa yang menerima barang ini, setelah memakainya atau setelah lewatnya suatu waktu tertentu, akan mengembalikannya (pasal 1740 BW). Sedangkan dalam perjanjian pinjam pakai yang digunakan oleh Pemerintah Daerah tidak ada klausul yang menyebutkan tentang jangka waktu penggunaan tanah tersebut. Selain itu, trotoar atau jalur pedestrian yang dibangun merupakan bangunan permanen, seperti apa pengembalian yang akan dilakukan pemerintah daerah kepada pemilik tanah, dan sampai kapan tanah milik warga tersebut akan digunakan, tidak ada kepastian disini yang dapat dterima oleh warga, oleh sebab itu warga kawasan jalan kemang raya merasa diperlakukan tidak adil. Selain Pasal $28 \mathrm{H}$ ayat 2 (dua), dalam ayat 4 (empat) juga dijelaskan sebagai berikut " Setiap orang berhak mempunyai hak milik pribadi 
Otentik's: Jurnal Hukum Kenotariatan (Vol 3, No. 1, Januari 2021)

p-ISSN 2655-5131 e-ISSN 2685-3612

dan hak milik tersebut tidak boleh diambil alih secara sewenang-wenang oleh siapapun" disebutkan bahwa setiap orang berhak mempunyai hak milik pribadi dan tidak boleh diambil secara sewenagwenang, apabila kita melihat apa yang terjadi dalam pembangunan trotoar atau jalur pedestrian di jalan Kemang Raya, jelas pasal ini telah dilanggar, karena warga di kawasan kemang raya jelas diperlakukan sewenag-wenang terhadap tanah miliknya yang digunakan untuk kepentingan umum yaitu pembangunan trotoar.

Sedangkan untuk status tanah yang telah dibongkar dan di bangun menjadi trotoar atau jalur pedestrian menjadi milik pemerintah, Untuk itu hal ini dianggap merugikan pemegang hak atas tanah dikarenakan pengalihan ha katas tanah dilakukan dengan pinjam pakai tanah. Seperti kita ketahui sebuah perjanjian pinjam pakai mengharuskan peminjam untuk mengembalikan apa yang di pinjam nya dalam jangka waktu yang telah disepakati bersama. Umntuk itu, apabila diperhatikan lebih dalam ada unsur kesewenag-wenangan yang dilakukan pemerintah daerah demi mewujudkan keindahan untuk pejalan kaki tetapi tanpa didasari merugiakn dan melanggar peraturan-peraturan yang mengaturnya.

\section{KESIMPULAN}

Penulis menyimpulkan hal-hal sebagai berikut :

1. Pelaksanaan Pengadaan Tanah bagi Pembangunan untuk Kepentingan Umum yang dilakukan dalam pembangunan jalur pedestrian di Jalan Keman Raya, Jakarta Selatan dilaksanakan secara langsung oleh Pemerintah Daerah Khusus Ibukota Jakarta dengan Dinas Bina Marga sebagai Pelaksana Pengadaan Tanah untuk pembangunan jalur pedestrian tersebut dengan warga atau pemilik tanah yang digunakan untuk pembangunan jalur pedestrian di jalan Kemang Raya. Penulis menemukan hal yang tidak sesuai dengan Undang-undang yang mengatur tentang pengadaan tanah bagi pembangunan untuk kpentingan umum, yakni Undang-undang Nomor 2 Tahun 2012 Tentang Pengadaan Tanah bagi Pembangunan Untuk Kepentingan Umum, yakni dalam hal pelaksana pengadaan tanah, berdasarkan Pasal 27 ayat (1) Undang-undang Nomor 2 Tahun 2012 yang berbunyi “ Berdasarkan penetapan lokasi pembangunan untuk kepentingan umum, instansi yang memerlukan tanah mengajukan pelasksanaan pengadaan tanah kepada lembaga pertanahan, selain itu dalam penjelasan Pasal 27 ayat (1) tersebut menjelaskan bahwa “ pengadaan tanah pada prinsipnya dilaksanakan oleh lembaga pertanahan, yang dalam pelaksanaannya dapat mengikutsertakan atau berkoordinasi dengan pemerintah provinsi atau pemerintah kabupaten/kota. Seharusnya dalam penyelenggaraan pengadaan tanah bagi pembangunan untuk kepentingan umum, lembaga pertanahan setempat dilibatkan sebagai pelaksana pengadaan tanah, akan tetapi dalam pembangunan jalur pedestrian di jalan Kemang Raya, justru lmbaga pertanahan tidak dilibatkan sama sekali, disini peneliti menganggap 
Otentik's: Jurnal Hukum Kenotariatan (Vol 3, No. 1, Januari 2021)

p-ISSN 2655-5131 e-ISSN 2685-3612

pembangunan jalur pedestrian di Jalan Kemang Raya tidak sesuai dengan undang-undang yang mengaturnya, yakni Undang-undang Nomor 2 Tahun 2012 tentang Pengadaan Tanah bagi Pembangunan Untuk Kepentingan Umum. Dalam pelaksanaan pengadaan tanah yang dilaksanakan di sepanjang Jalan Kemang Raya, yakni pembangunan jalur pedestrian tersebut menggunakan lahan bagian depan milik warga yang bertempat tinggal di kawasan Jalan Kemang Raya, akan tetapi pemilik lahan tidak mendapatkan kompensasi yang seharusnya seperti sebagaimana diatur dalam Pasal 5 Undang-undang Nomor 2 Tahun 2012 yang berbunyi “ Pihak yang berhak wajib melepaskan tanahnya pada saat pelaksanaan pengadaan tanah untuk kepentingan umum setelah pemberian ganti kerugian, atau berdasarkan putusan pengadilan yang telah memperoleh kekuatan hukum tetap, dan Pasal 36 yang berbunyi “ Pemberian ganti kerugian dapat diberikan dalam bentuk : uang, tanah pengganti, permukiman kembali, kepemilikan saham, dan bentuk lain yang disetujui oleh kedua belah pihak. Selain itu dijelaskan dalam Pasal 75 ayat (1) yang berbunyi "Dalam musyawarah sebagaimana dimaksuddalam pasal 68 pelaksana pengadaan tanah mengutamakan pemberian ganti rugi dalam bentuk uang. Jelas dalam pelaksanaan pembangunan jalur pedestrian di kawasan Jalan Kemang Raya Jakarta Selatan tidak sesuai dengan Undang-Undang No.2 Tahun 2012 tentang Pengadaan Tanah bagi Pembangunan untuk Kepentingan Umum, Untuk itu warga yang bertempat tinggal di kawasan Kemang Raya mengaharapkan kompensasi dari pemerinath daerah terkait penggunaan lahan milik nya.

2. Penyerahan hasil dan pengalihan hak atas tanah diatur dalam Pasal 48 ayat (1) Undang-undang Nomor 2 Tahun 2012 tentang Pengadaan tanah bagi pembangunan untuk kepentingan umum bahwa : "Lembaga pertanahan menyerahkan hasil Pengadaan tanah kepada instansi yang memerlukan tanah setelah "pemberian ganti kerugian kepada ihak yang berhak dan pelepasana hak sebagaimana yang dimaksud dalam pasal 41 ayat (2) huruf a telah dilaksanakan (bunyi pasal 41 ayat (2) huruf a adalah " pada saat pemebrian ganti kerugian pihak yang berhak menerima ganti kerugian wajib melakukan pelepasan hak")".

Dalam kasus pembangunan jalur pedestrian di Jalan Kemang Raya, pihak Lembaga Pertanahan justru tidak dilibatkan, tidak ada tim penilai untuk menilai harga tanah yang akan digunakan untuk umum tersebut, selain itu penyarahan tanah tidak dilakukan setelah pemberian ganti kerugian seperti yang dijelaskan pada pasal 48 ayat (1) terbut, melainkan dengan penandatanganan perjanjian kerja sama dalam hal ini perjanjian pinjam pakai tanah antara pihak yang memerlukan tanah dengan pihak yang berhak atau pemilik tanah. Untuk itu warga di kawasan Kemang Raya masih banyak yang tidak menyetujui nya, selain mengenai ganti rugi mereka juga merasakan ketidak adilan dan tdak adanya perlindungan hukum bagi para pihak 
Otentik's: Jurnal Hukum Kenotariatan (Vol 3, No. 1, Januari 2021)

p-ISSN 2655-5131 e-ISSN 2685-3612

yang tanah nya akan digunakan untuk pembangunan jalur pedestrian. Seharusnya penyerahan lahan dilakukan oleh lembaga pertanahan setelah dilakukan penilaian oleh jasa penilai dan penyerahan tanah dilakukan pada saat penandatangan Berita Acara Serah Terima diikuti dengan penandatangan ganti kerugian.

3. Berdasarkan Pasal $28 \mathrm{H}$ ayat (4) " setiap orang berhak mempunyai hak milik pribadi dan hak milik tersebut tidak boleh diambil alih secara sewenang-wenang oleh siapapun”. Berdasarkan pengakuan hak asasi manusia tersebut diatas, sepatutnya dalam kegiatan pengadaan tanah untuk pembangunan dilakukan dengan mengindahkan hak-hak tersebut. Jangan sampai masyarakat menjadi korban meskipun untuk alasan pembangunan. Dalam Pelaksanaan Pengadaan Tanah bagi pembangunan untuk kepentingan umum, ada beberapa asas-asas yang harus terpenuhi, menurut penulis ada penyimpangan asas asas pengadaan tanah dalam pembangunan jalur pedestrian di jalan Kemang Raya, yakni keadilan, kepastian dan kesepakatan. Asas Keadilan adalah memberikan jaminan penggantian yang layak kepada pihak yang berhak dalam proses Pengadaan Tanah sehingga mendapatkan kesempatan untuk dapat melangsungkan kehidupan yang lebih baik. Sedangkan dalam pengadaan tanah pembangunan jalur pedestrian di kawasan jalan Kemang Raya di rasakan tidak adil bagi para warga yang bidang tanah nya digunakan untuk kepentingan umum tanpa memberikan kompensasi dalam bentuk apapun kepada pihak pemilik tanah atau pihak yang berhak atas bidang tanah tersbut. Asas Kepastian adalah memberikan kepastian hukum tersedianya tanah dalam proses pengadaan tanah untuk pembangunan dan memberikan jaminan kepada pihak yang berhak untuk mendapatkan ganti kerugian yang layak. Dalam pembangunan jalur pedestrian di Jalan Keman Raya, warga seperti tdak mendapat kepastian dalam hal pemberian ganti kerugian, warga mengaku tidak mendapatkan ganti kerugian dalam bentuk apapun seperti yang tertuang dalam Pasal 36 Undang-undang Nomor 2 Tahun 2012 yakni : “Pemberian Ganti Kerugian dapat diberikan dalam bentuk : Uang, tanah pengganti, permukiman kembali, kepemilikan saham atau bentuk lain yang disetujui oleh kedua belah pihak". Asas Kesepakatan menurut penjelasan Pasal 2 Undang-undang Nomor 2 Tahun 2012 adalah "bahwa proses pengadaan tanah dilakukan dengan musyawarah para pihak tanpa unsur paksaan untuk mendapatkan kesepakatan bersama”. Dalam prakteknya terkait pembangunan jalur pedetrain di Jalan Kemang Raya, tidak terwujud kesepakatan antara pihak ynag membutuhkan tanah dengan pihak yang berhak atas tanah tersebut. Untuk itu sampai dengan saat ini pengadaan tanah tersebut belum rampung. Untuk itu, pembangunan Jalur pedestrian di kawasan Jalan Kemang Raya dinilai cacat hukum oleh beberapa pihak dikarenakan terdapat beberapa penyimpangan. 
Otentik's: Jurnal Hukum Kenotariatan (Vol 3, No. 1, Januari 2021)

p-ISSN 2655-5131 e-ISSN 2685-3612

\section{Saran}

Seharusnya setiap pelaksanaan pembebasan lahan dengan tujuan untuk kepentingan umum harus dilaksanakan sesuai dengan peraturan perundang-undangan yang berlaku yakni dalam hal ini Undang-undang Nomor 2 Tahun 2012. Selain itu, pemerintah daerah agar lebih memperhatikan hakhak masyarakat dan jangan sampai merugikan hak-hak mereka dalam hal kepemilikan tanah pribadi masyarakat. Kepentingan umum jangan sampai pelaksanaan nya merugikan kepentingan beberapa masyarakat, sehinggan msayarakat tidak menerima keadilan yang layak sebagai Warga Negara Indonesia, karena hak-haknya.

\section{DAFTAR PUSTAKA}

\section{BUKU}

Abdullah, Ali, Hukum Agraria di Indonesia dalam perkembangan pembentukan Hukum Tanah Nasional, Jakarta, Universitas Pancasila, 2018.

Abdurrahman, Pengadaan Tanah Bagi Pelaksanaan Pembangunan Untuk Kepentingan Umum Cet. Ke-1, Bandung, PT. Citra Aditya Bakti, 1994.

Badrulzaman, Mariam Darus, Kitab Undang-Undang Hukum Perdata Buku III Tentang Hukum Perikatan dengan Penjelasan, Bandung, PT. Alumni, 1983.

Chomzah, Achmad Ali, Hukum Pertanahan, Jakarta, PT. Prestasi Pustaka, 2002.

Firmansyah, Ade Arif, Pergeseran Pola Perlindungan Hukum Dalam Pengadaan Tanah Untuk Kepentingan Umum, Yogyakarta, PT. Graha Ilmu, 2018.

Gautama, Sudargo, Tafsiran Undang-Undang Pokok Agraria, Bandung, PT. Alumni 1981. Gozali, Djoni Sumardi, Hukum Pengadaan Tanah, Surabaya: UII Press, 2017.

Harsono, Boedi, Hukum Agraria Indonesia Sejarah Pembentukan Undang-Undang Pokok Agraria isi, dan pelaksanaannya, Cet. 4, Jakarta, Universitas Trisakti, 2015.

Hutagalung, Arie S, Tebaran Pemikiran Seputar Masalah Hukum Tanah, Jakarta, LPHI, 2005

Ibrahim, Jhony, Teori, metode dan penelitian hukum normative, Surabaya, PT. Bayu Medika, 2007.

Iriantoro, Agung, Pengadaan Tanah Untuk Pembangunan Yang Berorientasi Kesejahteraan Rakyat, Tangerang, PT. Mahameru Global Solusindo, 2020.

Ismatullah, Dedi, Hukum Perikatan, Bandung, CV. Pustaka Setia, 2011.

Limbong, Bernard, Pengadaan Tanah Untuk Pembangunan, Jakarta, PT. Margaretha Pustaka, 2011.

Lubis, M. Solly, Ilmu Pengetahuan Perundang-undangan, Bandung, PT. Mandar Maju, 2009

Mahendra, A.A, OK, Menguak Masalah Hukum Demokrasi dan Pertanahan, Cet.1, Jakarta, PT. Sinar Harapan, 1996.

Mahfud, MD, Politik Hukum di Indonesia, Edisi Revisi, Jakarta, PT. Rajawali Pers, 2009.

Mertokusumo, Sudikno, Bab-Bab Tentang Penemuan Hukum, Bandung, PT. Citra Aditya Bakti, 1993.

Nurlinda, Ida, Prinsip-prinsip Pembaharuan Agraria Perspektif hukum, Jakarta, PT. Rajawali Pers, 2009 
Otentik's: Jurnal Hukum Kenotariatan (Vol 3, No. 1, Januari 2021)

p-ISSN 2655-5131 e-ISSN 2685-3612

Rahardjo, Satjipto, Ilmu Hukum, Bandung, PT. Aditya Bakti, 2009.

Rubaie, Achmad, Hukum Pengadaan Tanah Untuk Kepentingan Umum, Malang, PT. Bayumedia, 2007.

Rusyaidi, Achmad, "Pengadaan Tanah Untuk Kepentingan Umum: Antara Kepentingan Umum dan Perlindungan HAM", diakses dari http: //prp makassar.WordpressCom/2009/02/2013, diakses pada 23 Oktober 2010.

Salindeho, John, Masalah Tanah dalam Pembangunan, Cet. Ke-2, Jakarta, PT. Sinar Grafika, 1998.

Salim, Pengantar Hukum Perdata Tertulis,Cet.IX, Jakarta, PT. Sinar Grafika, 2014. Salle, Aminuddin, Hukum Pengadaan Tanah, Jakarta, PT. Kreasi Total Media, 2007. Setiawan, Yudhi, Hukum Pertanahan Teori dan Praktik, Malang: PT. Baymedia, 2010.

Sitorus, Oloan dan Dayat Limbong, Pengadaan Tanah Untuk Kepentingan Umum, Yogyakarta,

PT. Mitra Kebijakan Tanah Indonesia, 2004.

Soemitro, Ronny Hanitijo, Metodologi Penelitian Hukum dan jurimetri, Jakarta, PT. Ghalia Indonesia, 1998.

Soekanto, Soerjono dan Sri Mamudji, Penelitian Hukum Normatif: Suatu Tinjauan Singkat, Cet.1, Jakarta, PT. Rajawali Press, 2001.

Soekanto, Soerjono, Pengantar Penelitian Hukum, Jakarta, UI Press, 2018.

Subekti, R Hukum Perjanjian,Cet. 10, Jakarta, PT. Intermasa, 1985.

, Hukum Perjanjian, Cet.21, Jakarta, PT. Intermasa, 2005. , Hukum Perjanjian, Cet. XX, Jakarta, PT. Intermasa, 2010.

Sumardjono, Maria S.W, Alternatif Kebijakan Pengaturan Hak Atas Tanah Beserta Bangunan, Jakarta, Kompas, 2007.

UGM Press, 2015. , Dinamika Pengaturan Pengadaan Tanah di Indonesia, Yogyakarta,

, Industri \& Perubahan Fungsi Sosial Hak Milik Atas Tanah, Yogyakarta, PT. Genta Publishing, 2000.

, Tanah Dalam Prespektif Hak Ekonomi Sosial dan Budaya, Jakarta, Kompas, 2008.

Sutedi, Adrian, Implementasi Prinsip Kepentigan Umum Dalam Pengadaan Tanah Untuk Pembangunan,Ed. 1, Cet.2, Jakarta, PT. Sinar Grafika, 2008.

Syah, Mudakir Iskandar, Dasar-dasar pembebasan tanah untuk kepentingan umum, Jakarta, PT. Jala Pratama, 2007.

Tim Pusat Bahasa, Kamus Besar Bahasa Indonesia, edisi keempat, Jakarta, Pusat Bahasa, 2008.

Wahyono, Padmo, Indonesia Negara Berdasarkan Atas Hukum, Cet.ke-2, Jakarta, PT. Ghalia Indonesia,1986.

Zaman, Nurus, Politik Hukum Pengadaan Tanah, Bandung, PT. Refika Aditama, 2016.

\section{PERTATURAN PERUNDANG - UNDANGAN}

Indonesia,Undang-undang Dasar Negara Republik Indonesia Tahun 1945.

Indonesia, Undang-Undang Republik Indonesia tentang Pengadaan Tanah Bagi Pembanguanan 
Otentik's: Jurnal Hukum Kenotariatan (Vol 3, No. 1, Januari 2021)

p-ISSN 2655-5131 e-ISSN 2685-3612

Untuk Kepentingan Umum Nomor 2 Tahun 2012.

Indonesia, Peraturan Presiden Tentang Pengadaan Tanah Bagi Pelaksanaan Pembangunan, Perpres No.36 Tahun 2005.

Indonesia, Peraturan Presiden Tentang Perubahan keempat atas Peraturan Presiden Nomor 71

Tahun 2012 Tentang Penyelenggaraan Pengadaan Tanah Bagi Kepentingan Umum No.148 Tahun 2015.

\section{INTRNET}

Legalstudies71.blogspot.com abi asmana sumber dari hukum perdata material marhainis abdulhay, sh dan kuhperdata. 